\title{
Development of Urea Coated with Neem (Azadirachta indica) to Increase Fertilizer Efficiency and Reduce Greenhouse Gases Emission
}

\author{
Yusminah Halaa*, Oslan Jumadia, Abd. Muisa, Hartatia, Kazuyuki Inubushib \\ ${ }^{a}$ Biology Department, Faculty of Mathematic and Natural Science, State University of Makassar, Jl. Dg Tata Raya, Makassar, 90224 Indonesia \\ ${ }^{b}$ Graduate School of Horticulture, Chiba University, Matsudo 271-8510, Japan \\ *Corresponding author: yushala12@gmail.com
}

\section{Article history}

Received :5 March 2014

Received in revised form :

19 April 2014

Accepted :3 May 2014

Graphical abstract

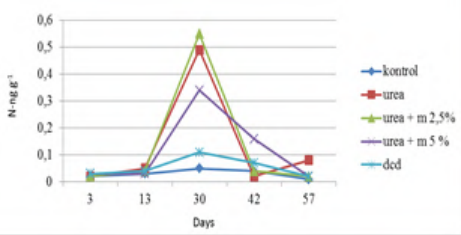

\section{Abstract}

Urea coated with neem fertilizer is one of the solutions to increase the efficiency of nitrogen fertilizer and reduce greenhouse gases emission. Inhibition of the nitrification rate of urea can reduce $\mathrm{NO}_{3}{ }^{-}$and $\mathrm{N}_{2} \mathrm{O}$ gas, and at the same time urea can be efficiently absorbed by the plants. Neem (Azadirachta indica) can suppress nitrification rate of $20-50 \%$, which is slightly lower than that of dyciandiamide (DCD) $(56-80 \%)$ Coating of urea granules was done by dipping urea granules in $1 \%$ neem oil, exposed it to $2.5 \%$ and $5 \%$ neem cake and then homogenized by rotation. The results were compared to urea coated with $5 \% \mathrm{DCD}$ The efficiency of fertilizer and nitrification inhibition were measured by nitrate and ammonium changes and fluxes of $\mathrm{N}_{2} \mathrm{O}$ gas. The results showed that application of urea coated with $5 \%$ neem on cabbage plants yielded the highest plant height. However, the leaf length and width were not significantly different with other urea treatments. Application of urea coated neem reduced nitrification rate and $\mathrm{N}_{2} \mathrm{O}$ emissions in the soil. Soil $\mathrm{CO}_{2}$ 's levels treated either with $2.5 \%$ or $5 \%$ neem coated urea showed the lowest levels of $\mathrm{CO}_{2}$ soil. This suggests that neem can reduce $\mathrm{N}_{2} \mathrm{O}$ and $\mathrm{CO}_{2}$ emissions from urea fertilizer as well as the capacity to reduce nitrification rate.

Keywords: Urea coated neem; nitrification; $\mathrm{N}_{2} \mathrm{O} ; \mathrm{CO}_{2}$

\begin{abstract}
Abstrak
Baja neem bersalut urea adalah salah satu pelarut yang digunakan untuk menambahkan kecekapan baja nitrogen dan megurangkan pelepasan gas rumah tanaman. Perencatan kadar nitrifikasi daripada urea boleh mengurangkan gas $\mathrm{NO}_{3}^{-}$dan $\mathrm{N}_{2} \mathrm{O}$, dengan pada waktu yang sama, urea dapat diserap oleh tumbuhan dengan berkesan. Neem (Azadirachta indica) dapat merencatkan kadar nitrifikasi sebanyak $20-50 \%$, iaitu sedikit lebih rendah daripada dyciandiamide (DCD) (56-80\%). Salutan granul urea telah dilakukan dengan mencelupkan granul urea ke dalam $1 \%$ minyak neem, lalu mendedahkannya kepada $2.5 \%$ dan $5 \%$ DCD. Kecekapan baja dan perencatan nitrifikasi telah diukur dengan meneliti pengubahan nitrate dan ammonium serta fluks daripada gas $\mathrm{N}_{2} \mathrm{O}$. Keputusan menunjukkan bahawa penggunaan $5 \%$ urea bersalut neem pada kubis telah menghasilkan ketinggian tanaman yang tertinggi, tetapi kepanjangan dan kelebaran daun tiada perbezaan yang ketara berbanding dengan rawatan urea jenis lain. Penggunaan urea bersalutan neem telah mengurangkan kadar nitrifikasi dan pelepasan $\mathrm{N}_{2} \mathrm{O}$ ke dalam tanah. Taraf $\mathrm{CO}_{2}$ dalam tanah dirawat dengan $2.5 \%$ atau $5 \%$ urea bersalutan neem adalah terendah. Ini mencadangkan bahawa neem dapat mengurangkan pelepsan gas $\mathrm{N}_{2} \mathrm{O}$ and $\mathrm{CO}_{2}$ daripada baja urea dan mampu mengurangkan kadar nitrifikasi.
\end{abstract}

Kata kunci: Urea bersalutan neem; nitrifikasi; $\mathrm{N}_{2} \mathrm{O} ; \mathrm{CO}_{2}$

CC 2014 Penerbit UTM Press. All rights reserved.

\subsection{INTRODUCTION}

Inhibition of nitrification rate is intended to improve the efficiency of the use or uptake of nitrogen $(\mathrm{N})$ by plants on agricultural area. This inhibition can increase the yields and reduce the elements of $\mathrm{N}$ that are released into the environment in the form of nitrate $\left(\mathrm{NO}_{3}{ }^{-}\right)$or nitrous oxide gas $\left(\mathrm{N}_{2} \mathrm{O}\right)$. Both of these forms are environmental pollutants, where $\mathrm{NO}_{3}{ }^{-}$can contaminate water or impact drinking water and induce lack of oxygen in the body (tissue), particularly in infants (methemoglobinemia), while $\mathrm{N}_{2} \mathrm{O}$ gas is one of the gases that causes global warming. ${ }^{1}$

Nitrification process is the oxidation of ammonium $\left(\mathrm{NH}_{4}^{+}\right)$ producing nitrate $\left(\mathrm{NO}_{3}^{-}\right)$, which involves 2 groups microorganisms; the group of ammonium oxidizing microorganisms (bacterial oxidation of ammonia, ammonia oxidizing Archea bacteria) and nitrite oxidizing bacteria. If the rate of nitrification process can be inhibited, the elements of $\mathrm{N}$ $\left(\mathrm{NH}_{4}{ }^{+}\right.$or $\left.\mathrm{NO}_{3}{ }^{-}\right)$can be efficiently absorbed by the plants and hence, reducing the formation of $\mathrm{N}_{2} \mathrm{O}$ or $\mathrm{NO}_{3}{ }^{-}$nitrate, which are elements of environmental pollution ${ }^{2}$. Some alternative options 
to reduce $\mathrm{N}_{2} \mathrm{O}$ or $\mathrm{NO}_{3}{ }^{-}$released to environment are optimizing supply of $\mathrm{N}$ in plants, the use of proportional animal and plant residues (organic matter), the use of controlled-release fertilizer and inhibition of the rate of nitrification ${ }^{3-4}$

Application of nitrogen fertilizer used in Indonesia are generally in the form of urea which contains about $46 \%$ nitrogen, but the nitrogen forms will be easily hydrolyzed in the formation of other nitrogen in the soil. The use of $\mathrm{N}$ fertilizer was very important in improving agricultural or plantation, but the efficiency is estimated only about $30-40 \%$, for approximately $30-50 \%$ of nitrogen application (urea) is lost due to nitrification (ammonium volatilization) and denitrification (leaching and runoff). Nitrification inhibitors have been recommended to use in conjunction with the nitrogen fertilizer (urea) with a certain proportion in agriculture area to minimize the risk of nitrogen released into the environment. ${ }^{5}$

Currently, there are two synthetic inhibitors of nitrification rate, i.e. nitrapyrin and dyciandiamide (DCD), which are widely known since they have been tested and are now commercially traded. The effect of Dyciandiamide to inhibit nitrification process on corn was observed by researchers in Makassar (experimental farm of Biology Department of UNM) and in Banjarmasin South Kalimantan (experimental farm of Universitas Lambung Mangkurat) where the result is effective in repressing the release of $\mathrm{N}_{2} \mathrm{O}$ to atmosphere and runoff $\mathrm{NO}_{3}{ }^{-}{ }^{3-4}$ However, owing to the expensive price, this has made the use of nitrification inhibitors not beneficial for farmers in Indonesia and unpopular other than in developed countries. ${ }^{6}$

In addition to the above synthetic materials, natural ingredients that have the power of repression are triterpenes and azardic contained in neem (Azardirachta indica). ${ }^{7}$ The result of the research that exhibited by the researcher in year 2009 both in laboratory and experimental farm scale, showed that administration of urea with neem is effective in reducing the rate of nitrification, which means that it has the potential of providing an efficient fertilizer for plants. The indicator used was the growth of cabbage plants given urea with neem.

Researches on neem as a nitrification inhibitor with urea have been done by the author in the initial stage of laboratory scale and pots with direct mixing with urea $(0.5-1 \%$ of the amount of given urea). ${ }^{8}$ However, the method or the way of introduction is quite troublesome for farmers, because they have to mix the neem with urea fertilizer first in balanced proportions before aplication.

In India, studies on the inhibitory effect have been scientifically tested on various types of crops that require considerable $\mathrm{N}$ elements, such as wheat, maize and rice. ${ }^{7,9-10}$ Neem's effectiveness in inhibiting nitrification process can take up to about 6 weeks, which depends on the condition, the soil, plants type and temperature. .,8-9 $^{-1}$

Previous results have shown that neem is quite effective in reducing the rate of nitrification of about $20-50 \%$ on a variety of soil textures. Although the inhibition of neem is still smaller than the chemical synthetic materials (DCD), it has capacity to increase the concentration of soil carbon content, compared to those synthetic chemicals. The results of this study also showed that side effects of neem to biotic factors (microbiological test of ammonium and nitrite oxidizing bacteria and enzymatic urease) of the land are not found, but instead increased the amount of soil microbial populations, especially soil fungi that play a role in the decomposition of minerals. ${ }^{8}$

The application of neem for $\mathrm{N}$ fertilizer will be very profitable for farmers in Indonesia because the cost for the purchase of fertilizer urea is lower and this will eventually help in increasing national food production sustainability. The aims of this study are to determine the effect of the use of urea coated neem on the growth and production of crops, improve the efficiency of nitrogen fertilizer use, inhibiting nitrification and reduce emissions of $\mathrm{CO}_{2}$ and $\mathrm{N}_{2} \mathrm{O}$ gases (greenhouse gases)

\subsection{EXPERIMENTAL}

\subsection{Preparation of Urea Coated with Neem}

Commercial neem materials was supplied by PT. Intaran Indonesia (http://indoneem.com) in the form of neem oil and neem cake. Dicyandiamide (DCD) which is a synthetic material (commercial) imported from Japan (Wako Co., Japan). DCD in this case is used as a comparison to the inhibition of nitrification by neem. All of the neem used was analyzed for total nitrogen content by the Kjeldahl digestion method. ${ }^{11}$ Urea coated neem fertilizer produced by coating urea granules by dipping urea granules in a solution of $1 \%$ neem oil. The next stage was the provision of neem cake as much as $2.5 \%$ and $5 \%$ of the weight of the urea granule and homogenised rotation. After even coating, the manure was dried under sunlight. Coating of urea with DCD as much as $5 \%$ of the weight of fertilizer granules using $1 \%$ glucose solution as an adhesive. After homogeneous coating of the fertilizer, it was then dried.

\subsection{Field Experiment Design}

The field research was carried out in the Experimental Farm of Biology Department, State University of Makassar. Plants used in this experiment were corn and cabbage. Retrieval of data was done as much as 2 times of crop rotation to see the retention of the retardant (inhibitor), growth and yield. Field experiments laid out were set in a completely random design. Determination factors such as changes in biotic and abiotic content of $\mathrm{NH}_{4}{ }^{+}$, $\mathrm{NO}_{3}{ }^{-}$from the soil surface, $\mathrm{N}_{2} \mathrm{O}$ and $\mathrm{CO}_{2}$ emissions, microbial biomass research were conducted during the field scale. ${ }^{12}$ Nitrogen content of the soil in the form of $\mathrm{NH}_{4}{ }^{+}$and $\mathrm{NO}_{3}{ }^{-}$were determined as above. $\mathrm{N}_{2} \mathrm{O}$ concentrations were measured using gas chromatography-electron capture detection (ECD) specification and measurement tools by Mosier et al. ${ }^{13}$

\subsection{Ammonium Oxidizing Bacterial Populations and Total Soil Fungi}

Population of ammonium oxidizing bacteria and soil fungi are as the indicator of soil's fertility. In this study, the amount of microbial analysis was conducted in the first week and latest weeks before the harvest. Medium that was used to calculate the approximate amount of ammonium oxidizing bacteria was AOB (ammonium oxidaser bacteria) medium while total fungi used PDA (potato dextrose agar) medium.

\subsection{RESULTS AND DISCUSSION}

\subsection{Effect of Neem Coated Urea Fertilizer on Plant Growth}

Characteristics of urea coated neem $2.5 \%$ are light brown, urea coated neem $5 \%$ is dark brown color and distinctive smell of neem. Urea coated with \%DCD 5 is pale yellow. The research aim in determining the response of the plants to neem coated urea fertilizer, conducted on cabbage and corn plants. Nitrogen concentration of urea given is $150 \mathrm{Kg}-\mathrm{N} / \mathrm{ha}$, KCL $36 \mathrm{Kg}$ $\mathrm{K}_{2} \mathrm{O} /$ ha, and GSP (phosphorus) were $36 \mathrm{Kg} \mathrm{P}_{2} \mathrm{O}_{5}$ per ha. Average vegetative of plant growth can be seen in Table 1 and Table 2. 
Table 1 The effect of urea coated neem fertilizer to vegetative growth of cabbage

\begin{tabular}{lccc}
\hline \multicolumn{1}{c}{ Teatment } & \multicolumn{3}{c}{ Measurement on 5 ${ }^{\text {th }}$ week } \\
& PH $(\mathbf{c m})$ & LL $(\mathbf{c m})$ & LW $(\mathbf{c m})$ \\
\hline Control & 37.43 & 14.125 & 3.748 \\
Urea & 37.461 & 16.014 & 4.063 \\
Urea + 2.5\% neem & 46.841 & 16.446 & 3.947 \\
Urea + 5\% neem & 48.75 & 12.297 & 3.953 \\
Urea + 5 \% DCD & 55.352 & 11.532 & 3.883 \\
\hline & & & \\
\hline Annotation: PH: Plant height; LL: Leaf long; LW: Leaf Wide
\end{tabular}

The response of plants to urea coated with $2.5 \%$ neem showed the best for all growth parameters. The effect of urea coated $2.5 \%$ neem on plant height $(\mathrm{PH})$ was similar to $5 \%$ DCD. Urea coated with $2.5 \%$ neem gave the highest yield of leaf long (LL) among all treatments even with urea shrouded 5\% DCD. Leaf wide (LW) plants treated with urea coated neem 2.5 $\%$ was similar to the LW plants treated with urea coated neem $2.5 \%$ and urea without neem.

Among the growth parameters, LW is the most decisive to the value crop (production) of plant because of the intensity of photosynthesis which ultimately influences plant biomass, which is determined by leaf area. For these parameters, the effect of neem, either $2.5 \%$ or $5 \%$ is better than $5 \%$ DCD . This suggests that neem is a better choice to produce plants with higher production compared to synthetic DCD. 2.5\% Neem turned out to be the most effective to reduce the nitrification process both if applied separately from urea ${ }^{8}$ and when applied by coating urea. Reduction of nitrification by neem can also increase the absorption of $\mathrm{N}$ from urea by plants. Value LW plants treated with $2.5 \%$ neem is almost the same as the LW plants treated with urea alone (without neem or DCD). This value is much higher than the LW control plants (without urea). It is clear that the source of plant $\mathrm{N}$ derived from urea, instead of other sources, e.g. soil or water, and neem was found to be supportive for good plant growth.

Table 2 Effect of urea coated neem to vegetative growth and production of corn

\begin{tabular}{lccc}
\hline \multicolumn{1}{c}{ Treatment } & PH & LL & LW \\
\hline Control & 137.53 & 58.05 & 5.74 \\
Urea & 133.29 & 63.46 & 6.38 \\
Urea + 2.5\% neem & 147.67 & 63.56 & 6.26 \\
Urea + 5\% neem & 137.73 & 60.54 & 5.94 \\
Urea + 5\% DCD & 131.16 & 58.8 & 5.73 \\
\hline
\end{tabular}

Annotation: PH: Plant height; LL: Leaf long; LW: Leaf Wide

Application of urea coated neem fertilizer provides better plant height than urea alone although slightly lower than urea coated with DCD. Leaf length and leaf width of plants treated with urea coated with neem were higher than plants given by urea coated with DCD, although plants treated with urea alone results almost same. This suggests that urea coated neem gave a good influence on plant growth.
3.2 Levels of Ammonium $\left(\mathrm{NH}_{4}^{+}\right)$and Nitrate $\left(\mathrm{NO}_{3}{ }^{-}\right)$Soil Treated with Neem Coated Urea

Analysis of levels of soil ammonium $\left(\mathrm{NH}_{4}^{+}\right)$and nitrate $\left(\mathrm{NO}_{3}^{-}\right)$ was done every ten days after planting, both in pot and field scale. The measurement of soil ammonium and nitrate level of plant has proven that the use of urea coated neem fertilizer can inhibit nitrification. Ability to inhibit the nitrification process has been demonstrated by the levels of soil nitrate treated with urea $+2.5 \%$ neem and urea $+5 \%$ neem were lower than the soil treated with urea alone. The ability of urea coated neem inhibited nitrification was lower than urea coated DCD (Table 3 and Table 4).

The ability of neem to reduce nitrification process can be seen in the levels of soil ammonium and nitrate. Ammonification process is the decomposition of biomass into ammonium and nitrification process is the decomposition of ammonium to nitrate. Both of the processes are performed by soil bacteria. Under natural conditions, urea, which is applied to the plant, will be mineralized to ammonium. Ammonium will then naturally undergo nitrification to nitrate.

The high nitrification process will lead to high soil nitrate levels. Although nitrate is a mineral that can be absorbed by plants but the plants' ability to absorb nitrates is lower than the ability of plants to absorb ammonium. In addition, large amounts of nitrate are too toxic to other life in the universe. Nitrification process would thus reduce $\mathrm{N}$ content that available to plants.

The ammonification process seems very high in the treatment of urea coated with 5\% neem. Highest soil ammonium levels were found in plants treated with urea covered with $5 \%$ neem, either at planting of the corn plant or of the cabbage plant. This level is much higher than that of the DCD. Nitrification inhibition appeared to be done by $5 \%$ neem. Lowest soil nitrate levels found in crop treated by urea coated neem $5 \%$. This suggests that neem in coated urea can also inhibit nitrification, same as when given separately. ${ }^{8}$

\subsection{Effect of Urea Coated Neem Fertilizer to Greenhouse} Gases Emissions Nitros Oxide $\left(\mathrm{N}_{2} \mathrm{O}\right)$ and Carbon Dioxide $\left(\mathrm{CO}_{2}\right)$

Analysis of levels of nitros oxide $\left(\mathrm{N}_{2} \mathrm{O}\right)$ and carbon dioxide $\left(\mathrm{CO}_{2}\right)$ produced from the processes of nitrification and microbial respiration was also done every ten days after planting and gas sampling was only performed on a scale gas field. The method used was closed chamber technique.

The results of measurements of soil $\mathrm{N}_{2} \mathrm{O}$ treated with $5 \%$ urea coated neem showed the level was higher than the levels $\mathrm{N}_{2} \mathrm{O}$ of urea coated DCD and the control treatment, but $\mathrm{N}_{2} \mathrm{O}$ levels are still lower than the levels of $\mathrm{N}_{2} \mathrm{O}$ from the treatment $2.5 \%$ urea coated neem or urea alone (Figure 1).

$\mathrm{N}_{2} \mathrm{O}$ production processes involve nitric bacterial activity. In the condition of nitrate oxidizing bacteria are in a normal state, the $\mathrm{N}_{2} \mathrm{O}$ production process will also run normally. The higher soil nitrate levels the greater levels of $\mathrm{N}_{2} \mathrm{O} . \mathrm{N}_{2} \mathrm{O}$ levels for all treatment plants appeared to increase to the highest level on day 30 after planting and decreased after that. On day 30 after planting, the highest levels of $\mathrm{N}_{2} \mathrm{O}$ appeared on urea without neem treatment (control). Levels of $\mathrm{N}_{2} \mathrm{O}$ in the treatment of urea coated with neem $(2.5 \%$ and $5 \%)$ was lower than that of urea without neem. This fact is in line with the result showed that the high nitrate levels was found in the urea treatment without neem. Levels of nitrate in the treatment of urea coated with neem are indeed lower than the levels of nitrate of urea without neem treatment (control). This suggests that the $5 \%$ neem coated urea can reduce $\mathrm{N}_{2} \mathrm{O}$ emissions. 
Table 3 Soil ammonium and nitrate level ( $\mathrm{g} / \mathrm{g}$ soil) of Cabbage plant

\begin{tabular}{lcc}
\hline \multicolumn{1}{r}{ Treatment } & Ammonium & Nitrate \\
\hline Control & 8.76 & 23.80 \\
Urea & 2.53 & 102.20 \\
Urea $+2.5 \%$ neem & 7.79 & 27.21 \\
Urea $+5 \%$ neem & 14.78 & 27.91 \\
Urea $+5 \%$ DCD & 13.19 & 25.77 \\
\hline
\end{tabular}

Table 4 Soil ammonium and nitrate level $(\mathrm{g} / \mathrm{g})$ of corn plant

\begin{tabular}{ccc}
\hline Treatment & Ammonium & Nitrate \\
\hline Control & 4.77 & 12.10 \\
Urea & 26.37 & 14.02 \\
Urea + 2.5\% neem & 18.19 & 16.83 \\
Urea + 5\% neem & 24.78 & 13.63 \\
Urea + 5\% DCD & 15.44 & 16.15 \\
\hline
\end{tabular}

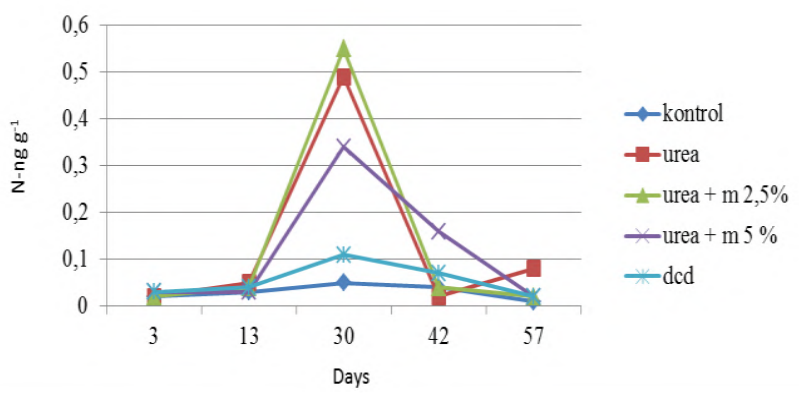

Figure 1 Soil $\mathrm{N}_{2} \mathrm{O}$ level from soil treated with urea coated neem and DCD

The effect of urea coated neem to the soil $\mathrm{CO}_{2}$ levels can be seen in Figure 2. The data collected from 5 weeks treatment showed that the highest $\mathrm{CO}_{2}$ content is in the $3^{\text {rd }}$ and $5^{\text {th }}$ week. This data is related to the condition of plant growth that reached the highest yield in week 5. Plant growth activity can influence the metabolism rate of the plant, including respiration process, that eventually influence the content of the $\mathrm{CO}_{2}$ of the plant. Soil's $\mathrm{CO}_{2}$ levels from soil treated either with urea coated with $2.5 \%$ neem or urea coated with $5 \%$ neem are lower than the levels of $\mathrm{CO}_{2}$ soil treated with urea coated with DCD and without urea. This suggests that neem can reduce $\mathrm{CO}_{2}$ emissions from urea fertilizer.

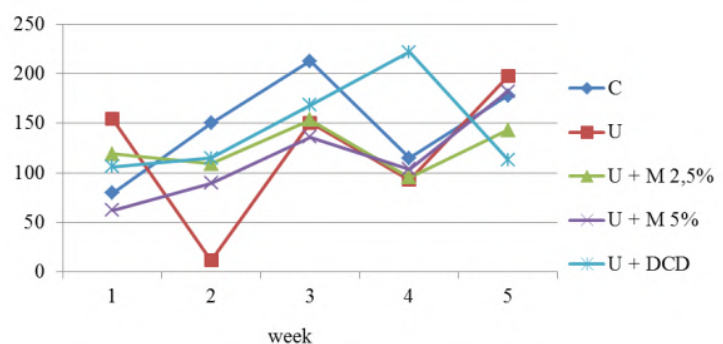

Figure 2 Soil $\mathrm{CO}_{2}$ levels from soil treated with urea coated neem and DCD
3.4 Ammonium Oxidizing Bacterial Populations and Total Soil Fungi

Ammonium oxidizing bacterial populations and total soil fungi as soil fertility parameters were measured on the first and third weeks in corn field. Soil microbial count results can be seen in Table 5. Soil microbial populations, both fungi and bacteria, after treatment with urea coated with neem are the highest soil microbial populations than the other treatment, urea alone or urea coated DCD. Neem seems to stimulate the growth of microbe very well so that the total number of fungi can reach 2 times more than that of urea shrouded DCD. The effect of neem against bacterial growth was not as big as the effect against fungi, however the total bacteria in the treatment of urea coated with neem was higher than urea alone or without urea.

Table 5 Population of ammonium oxidation bacteria and total fungi from corn soil

\begin{tabular}{ccccc}
\hline \multirow{2}{*}{ Treatment } & \multicolumn{2}{c}{ Fungi (cfu) } & \multicolumn{2}{c}{ Bacteria (cfu) } \\
\cline { 2 - 5 } & Week I & III & Week I & III \\
\hline Control & 32.00 & 31.00 & $1,016.67$ & $1,013.33$ \\
Urea & 47.00 & 51.00 & $1,273.33$ & $1,800.00$ \\
$\begin{array}{c}\text { Urea }+2.5 \% \\
\text { neem }\end{array}$ & 58.00 & 53.00 & $1,333.33$ & $1,900.00$ \\
$\begin{array}{c}\text { Urea }+5 \% \\
\text { neem }\end{array}$ & 36.00 & 87.00 & $2,400.00$ & $2,666.67$ \\
$\begin{array}{c}\text { Urea }+5 \% \\
\text { DCD }\end{array}$ & 32.66 & 42.33 & $1,540.00$ & $2,133.33$ \\
\hline
\end{tabular}

Neem is known to increase the carbon content of the soil. Therefore, treated 5\% urea coated neem can support the growth of ammonium oxidizing bacteria and soil fungi so that the population is higher than the microbial population in the other treatments. This cannot be observed in DCD.

\subsection{CONCLUSION}

The study suggests that the use of urea coated with neem can increase the efficiency of nitrogen fertilizer, inhibit nitrification and reduce emissions of $\mathrm{CO}_{2}$ and $\mathrm{N}_{2} \mathrm{O}$ gases as the greenhouse gases.

\section{Acknowledgement}

The authors would like to thank Universiti Teknologi Malaysia (UTM) for providing necessary facilities to carry out this research.

\section{References}

[1] IPCC. 2007. Summary for policymakers. In: Climate Change 2007: The physical Science Basis. Contribution of working group I to fourth assessment report of IPCC. Cambridge, UK and New York, USA: Cambridge University Press.

[2] G. P. Robertson and J. M. Tiedje. 1987. Nitrous Oxide Source in Aerobic Soils: Nitrification, Denitrification and Other Biological Processes. Soil Biol Biochem. 19: 187-193.

[3] O. Jumadi, Y. Hala, A. Muis, A. Ali, M. Palennari, K. Yagi, and K. Inubushi. 2008. Influences of Chemical Fertilizers and a Nitrification 
Inhibitor on Greenhouse Gas Fluxes in a Corn (Zea mays L.) Field in Indonesia. Microbes Environ. 23: 29-34.

[4] A. Hadi, O. Jumadi, K. Inubushi, and K. Yagi. 2008. Mitigation Options for $\mathrm{N}_{2} \mathrm{O}$ Emission from a Corn Field in Kalimantan, Indonesia. Soil Sci Plant Nutr. 54: 644-649.

[5] R. Prasad and J. F. Power. 1995. Nitrification Inhibitor for Agriculture, Health and the Environment. Adv. Agron. 54: 233-281.

[6] Jumadi, O. 2009. Impact of Land Management Practices on Greenhouse Gases Emissions and Microbial Communities Structure. A Doctoral Thesis (Submitted) to Graduate School of Science and Technology, divison of Advance Bioresources Science. Japan: Chiba University.

[7] S. N. Sharma and R. Prasad. 1996. Use of Nitrification Inhibitor (neem and DCD) to Increase N Efficiency In Maize-wheat Cropping System. Fertilizer Research. 44: 169-175.

[8] O. Jumadi and Y. Hala. 2013. Penekanan Laju Nitrifikasi dengan Penambahan Neem (Azardirachta indica) dan Efeknya Terhadap Mikroba Tanah. Sainsmat. 2(2) 108-115.
[9] D. Majumdar, H. Pathak, S. Kumar, and M. C. Jain. 2002. Nitrous Oxide Emission from a Sandy Loam Inceptisol Under Irrigated Wheat in India as Influenced by Different Nitrification Inhibitors. Agri. Ecosys. Environ. 91: 283-293.

[10] Malla, G., A. Bhatia, H. Pathak, S. Prasad, N. Jain, and J. Singh 2005. Mitigating nitrous oxide and methane emission from soil in rice-wheat system of the Indo-Gangetic plain with nitrification and urease inhibitors. Chemosphere. 58: 141-147.

[11] Anderson, J. M. and J. S. I. Ingram. 1989. Colometric Determination of Ammonium. In: Tropical Soil Biology and Fertility. ISSS, CAB International, Wallingford. 42-43.

[12] A. Hayashi, K. Sakamoto, and T. Yoshida. 1997. A Rapid Method for Determination of Nitrate in Soil by Hydrazine Reduction Procedure. Jpn J Soil Sci Plant Nutr. 68: 322-326.

[13] A. R. Mosier, J. N. Duxbury, J. R. Freney, O. Heinemeyer, and K. Minami. 1996. Nitrous Oxide Emission from Agriculture Fields: Assessment, Measurement and Mitigation. Plant Soil. 181: 95-108. 